UCRL-JC- 107481

PREPRINT

\title{
Corrosion of Copper-Based Materials in Irradiated Moist Air Systems
}

\author{
Donald T. Reed \\ Argonne National Laboratory \\ 9700 South Cass Avenue \\ Argonne, IL 6iv439-4837 \\ and \\ Richard A. Van Konynenburg \\ Lawrence Livermore National Laborafory \\ P.O. Box 808, L-352 \\ Livermore, CA 94550
}

Prepared for Submittal : Materials Research Society, Scientific Basis for Nuclear Waste Management XIV,

Boston, MA

November $26-28,1990$

Manuscript Date: November 1990

Publication Date: June 1991

JUL \& 51991

$+$

This is a preprint of a paper inlended for publication in a journal or proceedings. Since - changes may be made before publication, this preprint is made availoble with the under- standing that it will nol be cited or reproduced without the permission of the author.

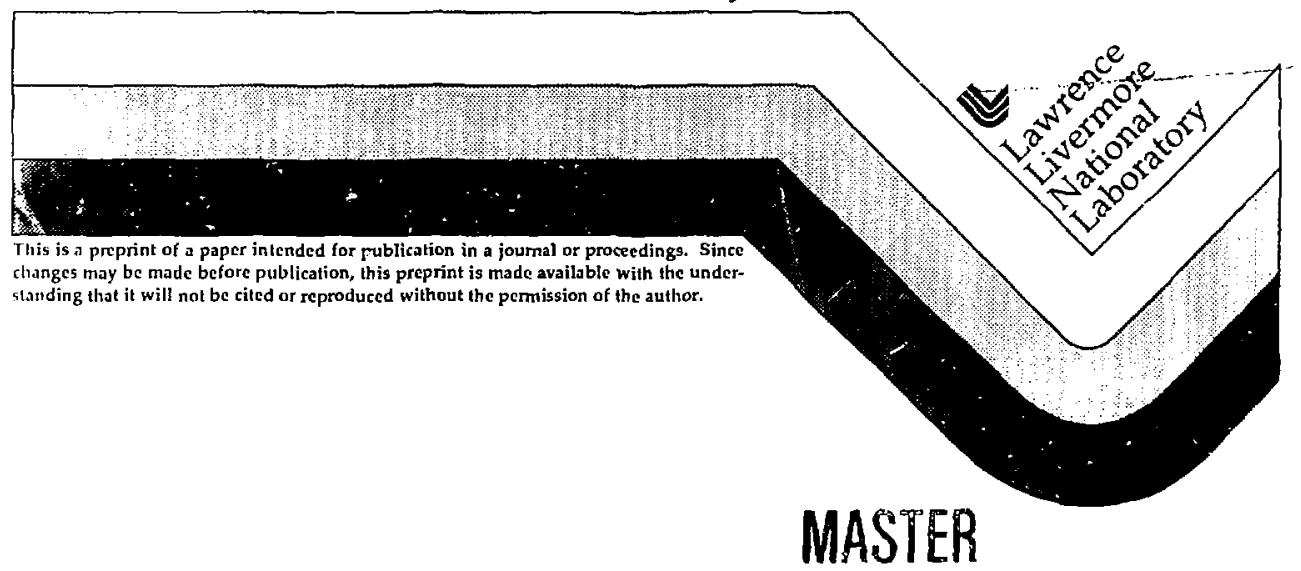

$$
\text { Lis }
$$




\section{DIS'IAIMIFH}

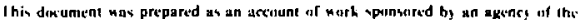

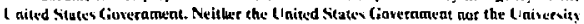

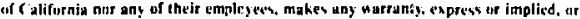
asumes any Ixeul liabilit) or respansibility for the urcuracy, cumpletenesv, or uscfulness of any information, appasatus, product, ur process disclosed, or represents that its use nould not infringe prisalely anned rights. Heferener herein ta amb specific commeicial productu precess, or service by trade name. trademark, manufaclurer, or ot herm ine. der's not necessarily senstitute ar imply its endorement, recommendation. or lasuring by the liniled silates Cioncrnment or the University of California. Ithe

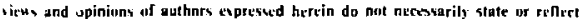

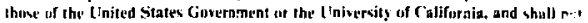
be used for adierlising or product endist siment purpales. 
DONALD T. RFED* AND RICHARD A. VAN KONYNENBURG**

*Chemical Technology Division, Argonne National Laboratory, 9700 South

Cass Avenue, Argonne, IL 60439-4837

** Lawrence Livermore National Laboratory, P. 0. Box 808, Livermore, CA 94550

\section{ABSTRACT}

The atmospheric corrosion of oxygen-free copper (CDA-102), 70/30 copper-nickel (CDA-715), and 7\% aluminum bronze (CDA-613) in an irradiated moist air environment was investigated. Experiments were performed in both dry and $40 \% \mathrm{RH}\left(990^{\circ} \mathrm{C}\right)$ air at temperatures of 90 and $150^{\circ} \mathrm{C}$. Initial corrosion rates were determined based on a combination of weight gain and weight loss measurements. Corrosion products observed were ident ified. These experiments support efforts by tise Yucca Mountain Project (YMP) to evaluate possible metallic barrier materials for nuclear waste containers.

\section{INTRODUCTION}

Oxygen-free copper (CDA-102), 70/30 copper-nickel (CDA-715) and aiuminum bronze (CDA-613) are being evaluated by the YMP as candidate materials for the construction of the high-level nuclear waste container in the mined geologic disposal system. After emplacement the container will be subjected to an irradiated air-steam environment. General atmospheric corrosion and, in particular the relationship between the radiolytic enviroment and the type and extent of corrosion observed, are important aspects in evaluating the long-term performance of these materials in the proposed repository.

The atmospheric corrosion of copper-based alloys has been relatively well established in nonirradiated systems [1,2]. Exposure to atmospheric conditions results in the following: initially a brown, presumably cuprite $\left(\mathrm{Cu}_{2} 0\right)$, film forms, followed by a dull ilack film, presumably tenorite (CuO), which in time will form a patina that can vary in color depending on the presence of other species in the gas phase. In low relative hunidity systems corrosion rates are low, ranging from 0.04 to $0.18 \mathrm{mg} / \mathrm{cm}^{2} / \mathrm{y}$. The rates obtained are strongly dependent on the relative humidity and the presence of anionic species such as chloride and sulfide in the gas phase.

In irradiated systems, however, much less is known about the corrosion behavior of copper-based alloys. This point was riade previously [3] and existing information about the nature of the phases genorated in irradiated moist air systems was summarized. Some work has already been done in connection with the high-level waste effort $[4,5]$ and nuclear-related research [6]. In our own work [3], we established that the irradiated moist air environment can, under some conditions, be very aggressive towards copper-based materials. Nitrogen oxides and nitric acid generated in the gas phase due to radiolys is resulted in the formation of copper nitrate phases which were associated with the formation of pits in coppernickel and oxygen-free copper. To further characterize the behavior of copper-based materials in irradiated moist air systems we performed a series of experiments designed to (1) establish the nature of corrosion products generated and (2) establish the initial rates of corrosion in an irradiated moist air environment.

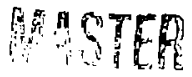


The expected environment during the initial phase of repository history is a gas phase that consists primarijy of air and water vapor. An important property of this gas phase is that the total pressure wit? be fixed at approximately 660 torr. This constraint will, most likely, limit the relative humidity.

Baseu on thermal calculations published by the YMP [7], relative humidities will not exceed $20 \%$ during the time that gamma radiation levels outside the container are significant (first $300 \mathrm{y}$ ). Initially, gamma levels may be as high as $0.1 \mathrm{Mrad} / \mathrm{h}$ for some of the "hotter" containers but will more typically be $0.01 \mathrm{Mrad} / \mathrm{h}$ for spent fuel.

\section{EXPERIMENTAL}

The copper-based materials used in the experiments were purchased commercially by the YMP. These were initially 4 by 1 by $8 \mathrm{~cm}$ specimens, originally obtained to perform stress corrosion experiments. For our experiments, they were cut into $0.2 \times 1 \times 2 \mathrm{~cm}$ specimens. These were subsequently polished to 600 grit, cleaned, thoroughly rinsed with highpurity water and air dried. After drying they were weighed to five significant figures $( \pm 0.00003 \mathrm{~g})$ on a Mettler $\mathrm{H}-20$ balance calibrated to NIST-traceabie standards.

Four specimens of a single material type were placed in each type $304 \mathrm{~L}$ stainless steel corrosion vessel. They were suspended by a Pyrex glass supporting rod and attached to this rod with stainless steel wire.

Either a dry air or $40 \% \mathrm{RH}\left(00^{\circ} \mathrm{C}\right.$ gas phase was placed in the vessel. For the dry air experiments, the vessels were evacuated, leak-checked overnight, reevacuated, and filled with Matheson UHP air

( $21.1=0.2$ mole\% $0_{2}, 78.9 \neq 0.2$ mole\% $N_{2}$, with $\langle 0.1$ mole\% carbon dioxide) to a total pressure of 540-560 torr. This corresponded to a total pressure of approximately $660 \pm 20$ torr at $90^{\circ} \mathrm{C}$ and $770 \pm 25$ torr at $150^{\circ} \mathrm{C}$.

The experiments containing water vapor were prepared by evacuating and leak-checking the irradiation vessel containing the coupons. This vessel was placed in an oven at $78^{\circ} \mathrm{C}$, allowed to equilibrate with the oven temperature, and then attached to a l-liter vessel containing approximately $50 \mathrm{~mL}$ of high-purity water that was also located in the oven. The air mixture was flowed through the 1-liter vessel for approximately one hour to establish a water-vapor saturated air mixture. The 1-1fter vessel was then sealed, allowed to equilibrate with the water for 20 minutes, and then expanded into the irradiation vessel containing the copper-based coupons. The pressure was recorded before and after the expansion of the gas (at $78^{\circ} \mathrm{C}$ ) and at room temperature after the vessel had cooled. The relative humidity was calculated based on the oven and room-temperature pressure difference and was $40 \% \div 3 \%$ for the experiments performed. This corresponds to approximately 200 torr of water vapor and 450 torr of air at $90^{\circ} \mathrm{C}$. The same gas phase, with respect to composition and total moles, was also present in the experiments performed at $150^{\circ} \mathrm{C}$.

After sample vessel preparation, the irradiations were performed in ovens set at $94 \pm 11^{\circ} \mathrm{C}$ and $152 \neq 2{ }^{\circ} \mathrm{C}$ and caliorated to NIST-traceable standards. The gamma dose rate was between 0.01 and $0.02 \mathrm{Mrad} / \mathrm{h}$ and was established using nitrous oxide dosimetry in vessels that were ideritical to those used in the corrosion experiments. The bulk composition of the gas phase present in each experiment was determined prior to initiation of tre experiment by gas chromatography.

Following irradiation, the composition of the gas phase was reanalyzed for both the initial components and some of the expected radijlytic molecular products (carbon dioxide, carbon monoxide, nitrous oxide). Here $\mathrm{CO}$ and $\mathrm{CO}_{2}$ are formed from reaction of oxygen with species on the vessel 
wall. Hydrogen and ammonia/NO analyses were also performed in some of the one-month experiments, but these species were not detected. After removal from the gamma facility, the vessels were disassembled and the coupons removed. The weights were redetermined on the same analytical balance to determine the change in weight due to exposure to the irradiated dry/moist air systems. All of the coupons were visually inspected on a $50 \mathrm{x}$ microscope for general appearance and evidence for locali<ed corrosion.

After visual inspection, three of the faur coupons were then cleaned (rinsed in 10\% HCI uTtrasonically for 1 or 2 minutes) to remove the corrosion buildup on the surface of the metal. These were then air dried and reweighed to determine the weight change. Corrosion rates were calculated based on weight difference between either (1) the initial and after-cleaning weight of the coupon or (2) the weight gain and aftercleaning weight of the coupon.

The fourth coupon was reserved for corrosion prouct analys is either directly with the $x$-ray diffractometer and/or Debye-Scherrer analys is of the corrosion products alone. Typical results are shown in Figure 1 for a copper specimen. After surface analyses, these coupons were retained as a record of the general corrosion observed and for more extensive surface analyses should they be warranted.
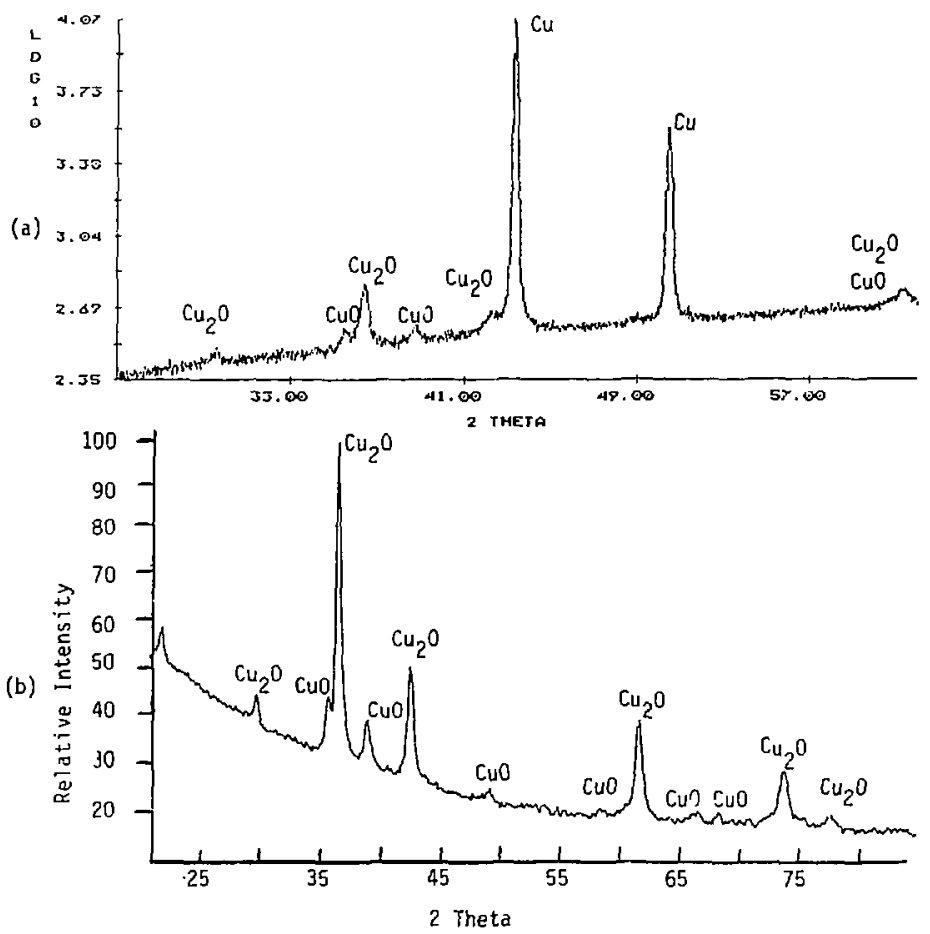

Figure 1. (a) X-ray diffractometer and (b) Debye-Scherrer Spectrum of Corrosion Products for Copper in Experiment CU-3R-150M. 
The initial composition of the gas phase was air $\left(21.1\right.$ mole $\% 0_{2}$. 79.9 mole $\% \mathrm{~N}_{2}$, and $<0.1$ mole" $\mathrm{CO}_{2}$ ) or air with approximately 30 mole? water vapor. Gamina irradiation resulted in the formation of carbon dioxide, carbon monoxide, nitrous oxide, and nitrogen dioxide/nitric acid as well as oxidizing products of water/oxygen (ozone, hydrogen peroxide, and the hydroxy and hydroperoxyl radicals).

In the $90^{\circ} \mathrm{C}$ experiment set, significant anounts of carbon dioxide and carbon monoxide were generated due to reaction with carbonaceous species at the vessel wall. He typically observed an increase in the $\mathrm{CO}_{2}$ content from $<0.1 \mathrm{~mole} \%$ to a concentration in the range of 0.3 to 0.8 mole $\frac{\mathrm{C}^{\circ}}{\mathrm{n}}$. Carbon monoxide was also found, at levels of 0.03 to 0.1 mole $\%$. The concentrations of both these species increased with absorbed dose and/or time.

Nitrous oxide was detected in all the final gas phase analyses performed. Concentrations ranged from trace amounts (0.002 mole: $)$ in the one-month experiment set to as high as 0.07 mole: in the 2.5 month sel. This species is radiolytically generated from nitrogen dioxide, so its presence is an indication that nitrogen dioxide, and nitric acid in the moist air systems, were being generated. Analyses for nitric acid (as nitrate) were performed for some of the experiments, with none detected. Greenish-white phases were observed on the surface of some of the coupons during their visual inspection further confirming, based on previous identification of this phase as $\mathrm{Cu}_{2}(\mathrm{OH})_{3} \mathrm{NO}_{3}$ [3], that $\mathrm{NO}$, was being generated.

The concentration of nitrogen in these experiments remained essentially conscant, with conversion to nitrous oxide and $\mathrm{NO}_{x} / \mathrm{NH}_{3}$ as the most likely deyradation pluducts. 0xygen, by reaction with the metals present and conversion to carbon dioxide and carbon monoxide, was reduced in concentration by $3-4$ mole\%.

Similar trends were noted in the $150^{\circ} \mathrm{C}$ experiment set. The extent of conversion of oxygen to carbon dioxide was, however, inore extensive with $\mathrm{CO}_{2}$ buildup reaching as high as 3 mole\%. Nitrous oxide vields were typically lower by a factor of two or more than those observed at $90^{\circ} \mathrm{C}$ particularly in the case of the copper and copper-nickel alloys.

\section{Corrosion of Oxygen-Free Copper}

The irradiation conditions of the experiments performed are given in Table 1 . These were the same for all three copper-based materials investigated. The corrosion rates observed and the corrosion products identified are given in Table I! for the experiments containing oxygen-free copper.

The extent of corrosion in the $90^{\circ} \mathrm{C}$ experiment set was relatively small leading to significant scatter in the rate data obtained. The overall appearance of the test specimens was a dull and slightly darkened copper color for the three experiments performed. The extent of corrosion was too small to identify the corrosion products using ARO and DebyeScherrer.

In the one-month experiment performed (CU-1R-90M) several greenish white deposits were observed on the surface of the metal. This experiment had been left at room temperature for srven days prior to disassembly so that several types of analyses could be performed on the gas phase. sinilar phases, to a lesser extent, were noted on the longer-term experimenis (3R-90t4 and 3R-90D) al though these were disassembled within $6 \mathrm{~h}$ of being renoved from the gamma facility. These phases were take:l to be 
TABLE I

Environmental and Irradiation Conditions for the Experiments Performed

\begin{tabular}{|c|c|c|c|}
\hline $\begin{array}{l}\text { Experiment } \\
\text { Designation } \\
(\mathrm{AB}-, \mathrm{CN}- \\
\text { or } \mathrm{CU}-)\end{array}$ & Environment & $\begin{array}{l}\text { Duration } \\
\text { (d) }\end{array}$ & $\begin{array}{l}\text { Dose Rate/ } \\
\text { Absorbed Dose } \\
(\text { Mrad/h)/Mrad }\end{array}$ \\
\hline $\begin{array}{l}-1 R-90 M \\
-3 R-90 M \\
-3 R-900\end{array}$ & $\begin{array}{l}94^{\circ} \mathrm{C}, 40 \% \text { RH O } 90^{\circ} \mathrm{C} \text { Air } \\
94^{\circ} \mathrm{C} \text {, } 40 \% \text { RH O } 90^{\circ} \mathrm{C} \text { Air } \\
94^{\circ} \mathrm{C} \text {, Dry Air }\end{array}$ & $\begin{array}{l}35 \\
73 \\
75\end{array}$ & $\begin{array}{l}0.021 / 17.4 \\
0.021 / 36.6 \\
0.021 / 37.6\end{array}$ \\
\hline $\begin{array}{l}-1 R-150 M \\
-3 R-150 M \\
-3 R-1500\end{array}$ & $\begin{array}{l}152^{\circ} \mathrm{C}, 40 \% \text { RH } 00^{\circ} \mathrm{C} \text { Air } \\
152^{\circ} \mathrm{C} \text {, } 40 \% \text { RH } 90^{\circ} \mathrm{C} \text { Air } \\
152^{\circ} \mathrm{C} \text {, Dry Air }\end{array}$ & $\begin{array}{l}30 \\
76 \\
78\end{array}$ & $\begin{array}{l}0.015 / 10.7 \\
0.011 / 20.0 \\
0.015 / 27.9\end{array}$ \\
\hline
\end{tabular}

TABLE II

Corrosion Rates and Corrosion Products Identified for the Copper (CU), Copper-Nickel (CN), and Aluminum Bronze (AB) Atmospheric Corrosion Experiments

\begin{tabular}{|c|c|c|c|c|}
\hline \multirow{2}{*}{$\begin{array}{l}\text { Experiment } \\
\text { Designation }\end{array}$} & \multirow{2}{*}{$\begin{array}{c}\text { Corrosion Rate } \\
\mathrm{mg} / \mathrm{cm}^{2} / \mathrm{y}\end{array}$} & \multicolumn{3}{|c|}{ Coriosion Products } \\
\hline & & & Major & Minor \\
\hline $\begin{array}{l}C U-1 R-90 M \\
C U-3 R-90 M \\
C U-3 R-90 D \\
C U-1 R-150 M \\
C U-3 R-150 M \\
C U-3 R-150 D\end{array}$ & $\begin{aligned} 1.5 & \pm 0.1 \\
0.56 & \pm 0.06 \\
0.14 & \pm 0.02 \\
2.6 & \pm 0.1 \\
2.3 & \pm 0.1 \\
1.6 & \pm 0.05\end{aligned}$ & $\begin{array}{l}\mathrm{ND} \\
\mathrm{ND} \\
\mathrm{NA} \\
\mathrm{Cu}_{2} \mathrm{O} \\
\mathrm{Cu}_{2} \mathrm{O} \\
\mathrm{Cu}_{2} \mathrm{O}\end{array}$ & & $\begin{array}{l}\mathrm{CuO} \\
\mathrm{CuO} \\
\mathrm{CuO}\end{array}$ \\
\hline $\begin{array}{l}C N-1 R-90 M \\
C N-3 R-90 M \\
C N-3 R-90 D \\
C N-] R-150 M \\
C N-3 R-150 M \\
C N-3 R-1500\end{array}$ & $\begin{aligned} 0.33 & \pm 0.05 \\
0.21 & =0.03 \\
0.12 & \pm 0.04 \\
1.4 & \pm 0.1 \\
1.1 & \pm 0.2 \\
0.48 & \pm 0.04\end{aligned}$ & $\begin{array}{l}\mathrm{Cu}_{2} \mathrm{O} \\
\mathrm{NA} \\
\mathrm{NA} \\
\mathrm{Cu}_{2} \mathrm{O} \\
\mathrm{CuO} \\
\mathrm{CuO}\end{array}$ & (brown spots) & $\begin{array}{l}\mathrm{CuO} \\
\mathrm{Cu}_{2} \mathrm{O} \\
\mathrm{Cu}_{2} \mathrm{O}\end{array}$ \\
\hline $\begin{array}{l}A B-1 R-90 M \\
A B-3 R-90 M \\
A B-3 R-90 D \\
A B-1 R-150 M \\
A B-3 R-150 M \\
A B-3 R-150 D\end{array}$ & $\begin{aligned} 0.71 & \pm 0.13 \\
0.23 & \pm 0.05 \\
0.16 & \pm 0.01 \\
3.0 & \pm 0.4 \\
1.2 & \pm 0.2 \\
0.89 & \pm 0.02\end{aligned}$ & $\begin{array}{l}\mathrm{ND} \\
\mathrm{ND} \\
\mathrm{ND} \\
\mathrm{Cu}_{2} \mathrm{O} \\
\mathrm{CuO} \\
\mathrm{Cu}_{2} \mathrm{O}\end{array}$ & & $\begin{array}{l}\mathrm{CuO} \\
\mathrm{Cu}_{2} \mathrm{O} \\
\mathrm{CuO}\end{array}$ \\
\hline
\end{tabular}

evilence for the formation of copper nitrates on the metal surface, by comparison with past results we have obtained, but were not formed in sufficient amounts to analyze directly.

The initial corrosion rate in the moist air experiments at $90^{\circ} \mathrm{C}$ was $1.5 \pm 1 \mathrm{mg} / \mathrm{cm}^{2} / y$ decreasing to $0.56 \pm 0.06 \mathrm{mg} / \mathrm{cm}^{2} / \mathrm{y}$ in the longer term experiment. These data were, however, widely scattered due to the low extent of corrosion present. A rate of $0.14 \pm 0.02 \mathrm{mg} / \mathrm{cm}^{2} / y$ was noted in the dry air experimert.

As expected, more extensive corrosion was observed at $150^{\circ} \mathrm{C}$. In the 30 d moist air (CU-1R-150M) experiment, a green-brown tarnish covered the 
surface of the coupon. Cuprite was ide:tified as the major corrosion product with some tenorite also detected. In the two longer term experiments (CU-3R-150M and CU-3R-1500) the cuprite remained as the major corrosion product with tenorite present as a minor phase. The general appearance of the moist air experiment was a brown color covered with black patches. There was no evidence of the green-white surface deposits, noted in the $90^{\circ} \mathrm{C}$ experiments, for either of the moist air experiments. The general appearance of the specimens in the dry air experiment was blackcolored scale that did not appear to be strongly adherent.

The corrosion rate data obtained for the specimens in the $150^{\circ} \mathrm{C}$ experiments were more reproducible owing to the greater extent of mass loss that occurred. The corrosion rate was $2.6 \pm 0.1$ and $2.3 \pm 0.1 \mathrm{mg} / \mathrm{cm}^{2} / \mathrm{y}$ in the $30 \mathrm{~d}$ and $76 \mathrm{~d}$ moist air experiments corresponding to penetration rates of 2.9 and 2.6 microns/y, respectively. These rates were factor's of two and seven higher than those observed for the analogous moist-air experiments performed at $90^{\circ} \mathrm{C}$. The extent of corrosion in the dry air experiment:- was $1.6 \pm 0.05 \mathrm{mg} / \mathrm{cm}^{2} / \mathrm{y}(1.8 \mathrm{microns} / \mathrm{y})$ which was comparable to but 1 iwer than those obtained in the moist air system.

\section{Carrosion of 70/30 Copper Nickel}

Ai $90^{\circ} \mathrm{C}$, the overall appearance of the specimens in the two moist-air experiments was a dul1 bronze color. Greenish-white phases surrounding a brown-colored center were noted on the surface of the coupons in bcth experiments. The brown center was identified as cuprite. The phases noted were or the surface of the coupon, with no significant pit formation Evident. General córrosion rates peasured were $0.33 \pm 0.05 \mathrm{mg} / \mathrm{cm}^{2} / \mathrm{y}$ in the $35 \mathrm{~d}$ experiment. This decreased to $0.21 \pm 0.03 \mathrm{mg} / \mathrm{cm}^{2} / \mathrm{y}$ in the $73 \mathrm{~d}$ experiment .

In the dry air $90^{\circ} \mathrm{C}$ experiment (CN-3R-90D), the coupons were silver in color (original color of the metal) with only very light tarnishing evident. The corrosion rate determined was $0.12 \pm 0.04 \mathrm{mg} / \mathrm{cm}^{2} / \mathrm{y}$ and was a factor of two lower than that observed in the moist air experiment. The extent of corrosion product formation in both the moist air and dry air experiments was too small to analyze by XRD. The brownish phase present in the $\mathrm{CN}_{\mathrm{S}}-1 \mathrm{R}-90 \mathrm{M}$ experiment was identified as cuprite.

Significantly mare corrasion was evident at $150^{\circ} \mathrm{C}$ resulting in specimens that were grey-black in color in the two moist air experiments. A dark bronze coloration was also noted at 50x magnification in lighter areas on the surface. A few greenish-white specks were noted on the surface. The specimens in the dry air experiment ( $C N-1 R-1500)$ were predominantly dark bronze in color with some black patches also evident. The major corrosion product identified in the $35 \mathrm{~d}$ experiment was cuprite with some tenorite present. This was reversed in both the longer-term experiments performed.

The rate of corrosion measured was $1.4 \pm 0.07 \mathrm{mg} / \mathrm{cm}^{2} / \mathrm{y}$ in the $35 \mathrm{~d}$, $150^{\circ} \mathrm{C}$ moist air experiment. This is a factor of four higher than that observed at $90^{\circ} \mathrm{C}$. This rate decreased to $1.1 \pm 0.2 \mathrm{mg} / \mathrm{cm}^{2} / \mathrm{y}$ in the $76 \mathrm{~d}$ experiment. These corresponds to penetration rates of 1.6 and $1.3 \mathrm{microns} / \mathrm{y}$, respectively. In the dry air experiment, the corrosion rate was $0.48 \pm 0.4 \mathrm{mg} / \mathrm{cm}^{2} / \mathrm{y}$, which is a factor of 2.4 lower than that otserved in the analogous moist air experiment.

\section{Corrosion of Aluminum Bronze}

At $90^{\circ} \mathrm{C}$, the two moist air experiments had a very light greenish tarnish but were mostly bronze in color. A few black patches were noted in the 73 d experiment. The extent of corrosicn was not sufficient to analyze 
using XRD. The general appearance in the dry air experiments (AB-3R-900) was similar but darker in color. At $50 x$ magnification a black colored phase with lighter patches that were more bronze in color (base metal) was noted. No evidence of localized corrosion was observed.

The rate of corrosion determined in the $35 \mathrm{~d}$ moist air experiment was $0.71 \pm 0.13 \mathrm{mg} / \mathrm{cm}^{2} / \mathrm{y}$. This decreased to $0.23 \pm 0.05 \mathrm{mg} / \mathrm{cm}^{2} / \mathrm{y}$ in the $73 \mathrm{~d}$ experiment. Penetration rates were 0.9 and 0.3 microns $/ y$, respectively. The corrosion rate in the dry air experiment was $0.16 \pm 0.01 \mathrm{mg} / \mathrm{cm}^{2} / \mathrm{y}$ which was comparable to but slightly lower than that observed in the analogous moist air experiment.

The extent of corrosion was again significantly higher in the $150^{\circ} \mathrm{C}$ experiment set. The general appearance of the specimens in the two moist air experiments was initially dirk bronze to black in color changing to a dark black-green speckled appearance in the longer term experiment. The predaminant corrosion product was cuprite in the $30 \mathrm{~d}$ experiment and tenorite in the $76 \mathrm{~d}$ experiment. The corrosion rates determined were $3.0 \pm 0.4 \mathrm{mg} / \mathrm{cm}^{2} / \mathrm{y}$ and $1.2 \pm 0.15 \mathrm{mg} / \mathrm{cm}^{2} / \mathrm{y}$ in the $35 \mathrm{~d}$ and $76 \mathrm{~d}$ experiments, respectively. These were a factor of four higher than in the analogous experiments performed at $90^{\circ} \mathrm{C}$.

In the dry air experiment (AB-3R-150D) the general appearance of the specimens was black to dark gray. The major corrosion product was cuprite iather than tenorite as was the case in the moist air experiment. The corrosion rate determined was $0.89 \pm 0.02 \mathrm{mg} / \mathrm{cm}^{2} / y$ which was slightly lower than that observed in moist air and a factor of 5.5 higher than that observed at $90^{\circ} \mathrm{C}$.

\section{DISCUSSION}

The atmospheric corrosion of metals is ge:erally categorized into three distinct regimes with respect to relative humidity (low, intermediate, and vapur saturated). The low humidity regime is characterized by direct interaction of the gaseous species with the metal surface. Here surface oxidation is the dominant process and the rates of corrosion ara usually quite low. In the intermediate humidity regime, a thin surface layer of water exists. The rate of corrosion is substantially greater than in the low humidity regime and trace constituents of the gas phase have a greater role in defining the nature of the corrosion observed since they can be concentrated in the thin film of water. In the high-humidity regime, the general corrosion observed approaches that of aqueous systems.

In irradiated systems, the same corrosion regimes have aiso been observed. The relative humidity at which the transition between low and internediate humidity regimes occurs is not clear-cut, with values of $30 \% \mathrm{RH}$ to $80 \%$ RH reported in the $i$ iterature. This value is expected to be material-specific and probably depends on the temperature and trace constituents present. In the irradiated moist dir system, the trace constituents of interest are the fixation products of nitrogen $\left(\mathrm{NO}_{x}\right.$ and ammonia) and the oxidizing species that are generated as radiolytic products of water and oxygen (ozone, hydrogen peroxide, and the $\mathrm{OH}$, and $\mathrm{HO}_{2}$ free radicals). Since the concentration of these species depends on both the dose rate and the absorbed dose, an added complexity in the irradiated system is the competition between the interaction of the radiolytic products generated and general corrosion processes.

The set of experiments reported herein were performed in the low humidity regime $\left(40 \% \mathrm{RH}\right.$ at $90^{\circ} \mathrm{C}$ and $0.06 \% \mathrm{RH}$ at $\left.150^{\circ} \mathrm{C}\right)$ al though the water vapor content of the gas phase was $30 \mathrm{~mole} \%$. The general corrosion behavior we observed for these systems was similar to that observed in nonirradiated systems in that cuprite and tenorite were the predominant corrosion products identified. In all cases cuprite was the initial product observed changing over to tenorite as increastd oxidation occurred. 
This result is significantly different from what we previously observed at gamma dose rates that were effectively ten times higher. In the higher dose rate and total pressure experiments [3], nitrate phases, in the case of both copper-nickel and aluminum bronze, were the predominant corrosion priducts and appeared as a minor product on the oxygen-free copper specimens.

The relative rates of corrosion observed decreased in the order of copper $>$ copper-nickel $=$ aluminum bronze in the moist air $90^{\circ} \mathrm{C}$ experiments. This same order was noted in the lang term moist air experiment at $150^{\circ} \mathrm{C}$. In the dry air experiments, no consistent trend was observed with all three having the same rate of corrosion at $90^{\circ} \mathrm{C}$ and copper-nickel undergoing the least corrosion at $150^{\circ} \mathrm{C}$.

The vast majority of data for copper-based materials relates their behavior in outdoor environments. Typical values for the atmospheric corrosion of copper-based materials subjected to long-term exposures of dry air (at ambient temperatures) are in the range of 0.04 to $0.18 \mathrm{mg} / \mathrm{cm}^{2} / \mathrm{y}$ [8]. Some data were, however, reported for oxygen-free couper in air-steam conditions in the same humidity regime as in our experiments. At $150^{\circ} \mathrm{C}$ [4], corrosion rates of $2.45,1.39$. and $0.88 \mathrm{microns} / \mathrm{y}$ were obtained for $1-, 4-$, and 10 -month exposure times, respectively. This compares to 3.5 and 2.7 microns/y we obtained in 1 -month and 2.5 -month experiments at the same temperature at a gamma dose rate of $0.02 \mathrm{Mrad} / \mathrm{h}$. Although some of the experimental methodology differed, there was a significant enhancement of corrosion, due to the gamma radiation present, by a factor of approximately 1.5 .

In the experiments we performed, the total pressures of the dry and moist air experiments were approximately the same. The gas phases, however, differed in that water vapor replaced some of the air (particularly oxygen) as the source of oxidizing species. Radiolytically only ozone, nitrogen fixation products and associated transients were generated in the dry air system. The presence of water vapor resulted in a a partial replacement of these species with the $\mathrm{OH}$ and $\mathrm{HO}_{2}$ free radicals as well as molecular products such as hydrogen peroxide.

The effect of replacing air with water vapor can be evaluated, on a preliminary basis, by comparing the corrosion rates observed in the dry and moist air experiments. At $90^{\circ} \mathrm{C}$, corrosion rates determined were significaitly lower in the dry air experiments. This was also true at $150^{\circ} \mathrm{C}$. Although further work is needed, this result is consistent with the more strongly oxidizing environment present when water vapor, rather than oxygen, is subjected to ionizing radiation.

\section{ACKNOWLEDGEMENT}

The authors gratefully acknowledge B. Tani who performed the corrosion product analyses reported herein, $F$. Schmitz for assistance in operating the gamma irradiation facility, and J. Emery who assisted in sample preparation. This work was supported by the U.S. Department of Energy, Office of Civilian Radioactive Waste Management, Yucca Mountain Project, under 4 itract Number W-7405-ENG-48, with Lawrence Livermore National Laboratory. 
1. H. Leidheiser, The Corrosion of Copper, Tin and Their Al ioys, John Wiley and Sons, Inc., New York (1971).

2. G. E. Gdowski and D. B. Bullen, "Survey uf Degradation Modes of Candidate Materials for High-Level Radioactive-Waste Disposal Containers, Oxidation and Corrosion," Lawrence Livermore National Laboratory report UCID-21362, vol. 2 (1988).

3. D. T. Reed, V. Swayambunathan, B. S. Tani, and R. A. Van Konynenburg, "Corrosion Production Identification and Relative Rates of Corrosion of Candidate Metals in an Irradiated Ai,-steam Environment," Mat. Ras. Soc. Symp. Proc. Vol. 176, 517 (1990).

4. "Feasibility Assessment of Copper-Based llas'e Package Container Materials in a Repository in Basalt, "Rockwell Hanford Operations report 50-BWI-TA-023 (1986).

5. W. H. Yunker and R. S. Glass, "Long-Term Corrosion Behavior of CopperBase Materials in a Gamma Irradiated Environment," Mat. Res. Soc. Symp. Proc. Vol. 84, 579 (1987).

6. A. V. Byalobzheskii, Radiation Corrosion, Izdatel' Stuo "Nauk, "Moskua (1976).

7. W. C. O'Neal, D. W. Gregg, J. N. Hockman, E. W. Russel1, and W. Stein, "Preclosure Analysis of Conceptual Waste Package Designs for a Nuclear Waste Repository in Tuff," Lawrence Livernore National Laboratary report UCRL-53595 (1984).

8. A. W. Tracy, "Symposium on Atmospheric Corrosion of Non-Ferrous Meta 15," ASTM-STP No. 175, 67 (1955). 